\title{
SIFAT OPTIK DAN STRUKTUR KRISTAL MATERIAL PEROVSKITE YANG DISINTESIS DARI BATERAI BEKAS MOBIL
}

\author{
AYI BAHTIAR*, NABILA ASY SYIFA, EUIS SITI NURAZIZAH, LUSI SAFRIANI \\ Departemen Fisika Fakultas MIPA Universitas Padjadjaran, \\ Jl. Raya Bandung-Sumedang Km 21, Jatinangor 45363 \\ * email : ayi.bahtiar@phys.unpad.ac.id
}

\begin{abstract}
Abstrak. Sel-surya berbahan aktif material perovskite telah banyak menarik perhatian banyak peneliti, karena mampu menghasilkan efisiensi di atas 20\%, mendekati sel-surya komersial Silikon. Namun, material timbal halida $\left(\mathrm{PbI}_{2}\right)$ sebagai material utama pembentuk material perovskite $\mathrm{CH}_{3} \mathrm{NH}_{3} \mathrm{PbI}_{3}$, harganya masih cukup mahal, sehingga menjadi kendala untuk dapat digunakan sebagai material aktif sel-surya, jika sel-surya diproduksi secara massal. Diperlukan sumber material lain yang tersedia melimpah, murah dan mudah dalam pemrosesannya untuk membuat material $\mathrm{PbI}_{2}$. Sebagai alternatif, sumber material timbal untuk membuat material timbal iodida $\left(\mathrm{PbI}_{2}\right)$ yang tersedia melimpah adalah baterai mobil. Material elektroda dari baterai mobil terdiri dari timbal sebagai katoda dan timbal dioksida sebagai anoda. Material-material tersebut berupa bubuk sehingga mudah untuk disintesis menjadi $\mathrm{PbI}_{2}$ melalui reaksi kimia sederhana. Keberhasilan mensintesis material $\mathrm{PbI}_{2}$ dari material bekas elektroda mobil menjadi kunci bagi pengembangan sel-surya perovskite yang berbiaya murah. Telah dilakukan sintesis $\mathrm{PbI}_{2}$ dari elektroda bekas baterai mobil melalui reaksi kimia. Hasil pengukuran EDS menunjukkan bahwa $\mathrm{PbI}_{2}$ hasil sintesis memiliki kemurnian $95 \%$ dan memiliki komposisi atomik yang lebih baik daripada produk komersial. Spektra UV-Vis dan XRD dari film $\mathrm{PbI}_{2}$ hasil sintesis memiliki karakteristik yang sama dengan produk komersial, sehingga hasil sintesis ini dapat dijadikan sebagai material perovskite $\mathrm{CH}_{3} \mathrm{NH}_{3} \mathrm{PbI}_{3}$ untuk sel-surya. Material perovskite yang dispin-coating di atas lapisan titanium dioksida memperlihatkan struktur kristal perovskite. Hasil riset ini menunjukkan bahwa material elektroda baterai bekas mobil dapat dijadikan sebagai material aktif selsurya perovskite yang murah, sehingga dapat meningkatkan nilai ekonomi limbah baterai bekas melalui pemanfaatan timbal menjadi material perovskite yang bernilai tinggi.
\end{abstract}

Kata kunci : sel-surya, perovskite, baterai bekas mobil, timbal oksida, timbal iodida

Abstract. Perovskite solar cells have attracted many researchers, because it can produce efficiency above $20 \%$, which is close to silicon commercial solar cells. However, lead halide $\left(\mathrm{PbI}_{2}\right)$ material as the main material for perovskite $\mathrm{CH}_{3} \mathrm{NH}_{3} \mathrm{PbI}_{3}$, is still quite expensive, making it an obstacle to be used as an active solar cell material for massal production. Other abundance available sources of material, cheap and easy to be processed into $\mathrm{PbI}_{2}$ are highly required. Alternatively, the available and abundance source of lead material for making the lead iodide $\left(\mathrm{PbI}_{2}\right)$ is the waste of car battery. The electrode of the car battery consists of lead $(\mathrm{Pb})$ as cathode and lead dioxide $\left(\mathrm{PbO}_{2}\right)$ as anode. Theese materials are powders that are easy to synthesize into $\mathrm{PbI}_{2}$ through simple chemical reactions. The successful synthesis of $\mathrm{PbI}_{2}$ from used car electrodes is a key for development of low-cost perovskite solar cells. $\mathrm{PbI}_{2}$ from the electrode car battery was succesfully synthesized through a simple chemical reaction. EDS measurements show that synthesized $\mathrm{PbI}_{2}$ has a purity $95 \%$ and has a better atomic composition than commercial products. The UV-Vis and XRD spectra of synthesized $\mathrm{PbI}_{2}$ films have the same characteristics as commercial products, so the result of this synthesis can be used as perovskite $\mathrm{CH}_{3} \mathrm{NH}_{3} \mathrm{PbI}_{3}$ material for solar cells. The perovskite films were succesfully spin-coated onto FTO coated by titanium dioxide layer, which was proved by the

JIIF (Jurnal Ilmu dan Inovasi Fisika), ISSN: 2549-0516 
characteristic of perovskite crystal structure in its XRD pattern. The results of this study also demonstrate that the used car battery can be used as an cheap active material of perovskite solar cell, thereby increasing the economic value of used car battery through the utilization it into valuable perovskite material.

Keywords : solar cells, perovskite, used car battery, lead oxide, lead iodide

\section{Pendahuluan}

Kebutuhan energi, khususnya energi listrik semakin meningkat tiap tahunnya seiring dengan peningkatan jumlah penduduk. Di sisi lain, mayoritas kebutuhan energi listrik mengandalkan bahan bakar fosil berupa minyak bumi, yang saat ini cadangan bahan bakar fosil semakin berkurang. Penggunaan minyak bumi juga menyebabkan pemanasan global dan pencemaran lingkungan. Menurut Kepala Badan Geologi, Kementrian Energi dan Sumber Daya Mineral (ESDM) Republik Indonesia cadangan minyak bumi di Indonesia hanya cukup untuk 18 tahun kedepan, sedangkan gas bumi masih bisa mencukupi hingga 61 tahun lagi, kemudian cadangan batubara diperkirakan habis dalam waktu 147 tahun lagi [1]. Dengan demikian perlu dicari sumber energi listrik alternatif untuk memenuhi kebutuhan energi, khususnya energi listrik. Salah satu energi alternatif yang dapat diperbaharui (renewable energy) sebagai pengganti bahan bakar fosil adalah sel surya (solar cell) yang mampu mengkonversi energi matahari langsung menjadi energi listrik tanpa menghasilkan gas buangan apapun atau bebas karbon [2].

Sel-surya dipercaya mampu menjadi sumber energi alternatif yang ramah lingkungan dan mudah digunakan secara massal $[2,3]$. Saat ini, berbagai sel-surya sudah dibuat dan dikomersialisasi menggunakan berbagai material sebagai material laisan aktifnya, seperti silikon, galium arsenida, cadmium telurida, silikon amorf, sel-surya dye, sel-surya organik/polimer dan sel-surya hibrid organik-inorganik [45]. Namun penggunaannya secara massal sebagai sumber energi listrik saat ini masih terkendala biaya produksi yang tinggi. Saat ini, sel-surya berbahan aktif material campuran bahan halida-organik/anorganik dengan struktur perovskite telah banyak menarik perhatian banyak peneliti, karena mampu menghasilkan efisiensi di atas $15 \%$ [6-8]. Khususnya bahan perovskite $\mathrm{CH}_{3} \mathrm{NH}_{3} \mathrm{PbI}_{3}$ (metilamonium timbal halida) telah menghasilkan efisiensi sebesar 21\% [9]. Namun, material timbal halida $\left(\mathrm{PbI}_{2}\right)$ sebagai material utama pembentuk material perovskite $\mathrm{CH}_{3} \mathrm{NH}_{3} \mathrm{PbI}_{3}$, harganya masih cukup mahal, sehingga menjadi kendala untuk dapat digunakan sebagai material aktif sel-surya, jika sel-surya diproduksi secara massal. Diperlukan sumber material lain yang tersedia melimpah, murah dan mudah dalam pemrosesannya untuk membuat material $\mathrm{PbI}_{2}$ agar sel-surya perovskite berbahan aktif $\mathrm{CH}_{3} \mathrm{NH}_{3} \mathrm{PbI}_{3}$ dapat diproduksi dengan biaya murah dan ramah lingkungan, sehingga mampu bersaing dengan sumber energi listrik lainnya.

Salah satu sumber material timbal untuk membuat $\mathrm{PbI}_{2}$ yang tersedia melimpah adalah baterai mobil. Di Indonesia, pengguna mobil sangat banyak dan secara rutin setiap 2 tahun, baterai mobil harus diganti. Material elektroda dari baterai mobil terdiri dari timbal $(\mathrm{Pb})$ sebagai katoda dan timbal dioksida $\left(\mathrm{PbO}_{2}\right)$ sebagai anoda. Material-material tersebut berupa bubuk sehingga mudah untuk disintesis menjadi $\mathrm{PbI}_{2}$ melalui reaksi kimia. Keberhasilan mensintesis material $\mathrm{PbI}_{2}$ dari material bekas elektroda mobil akan menjadi kunci bagi pengembangan sel-surya perovskite yang berbiaya murah. Permasalahan utama dalam mensintesis $\mathrm{PbI}_{2}$ dari baterai 
mobil adalah tingkat kemurnian $\mathrm{Pb}$ dan $\mathrm{PbO}_{2}$ dari baterai bekas, karena selama digunakan telah mengalami reaksi dengan elektrolit, umumnya asam sulfat. Karena itu, proses pemurnian $\mathrm{Pb}$ dan $\mathrm{PbO}_{2}$ menjadi kunci utama untuk menghasilkan $\mathrm{PbI}_{2}$ yang memiliki kualitas yang sama dengan produk komersial.

\section{Metode Penelitian}

Bahan yang digunakan adalah baterai bekas mobil yang memiliki kandungan timbal $(\mathrm{Pb})$ sebagai katoda dan timbal dioksida $\left(\mathrm{PbO}_{2}\right)$ sebagai anoda. Material $\mathrm{PbI}_{2}$ komersial dibeli dari Sigma Aldrich dengan kemurnian $>95,0 \%$. Bahan lain yang digunakan dalah kalium iodida (KI), 2-propanol (IPA), asam asetat $\left(\mathrm{CH}_{3} \mathrm{COOH}\right)$, $\mathrm{N}-\mathrm{N}$-dimetilformamida (DMF), $\mathrm{CH}_{3} \mathrm{NH}_{3} \mathrm{I}$ (MAI) dan klorobenzen. Asam klorat $(\mathrm{HCl})$ dan asam nitrat $\left(\mathrm{HNO}_{3}\right)$ dibeli dari Sigma Aldrich. Sintesis $\mathrm{PbI}_{2}$ dilakukan dengan menggunakan reaksi kimia larutan.

Baterai bekas mobil dipotong bagian atasnya, cairan elektrolitnya dibuang kemudian dicuci beberapa kali dengan air deionisasi dan dikeringkan selama 3 hari. Material timbal diperoleh dari katoda $\left(\mathrm{PbO}_{2}\right)$ dan anoda $(\mathrm{Pb})$. Namun, karena hasil pengukuran EDS (Energy Dispersive Spectroscopy) menunjukkan bahwa bubuk $\mathrm{Pb}$ mengandung banyak pengotor, seperti karbon (C) dan alumunium (Al), maka hanya bubuk $\mathrm{PbO}_{2}$ saja yang digunakan. Serbuk coklat gelap $\mathrm{PbO}_{2}$ pertama kali dicuci dengan $\mathrm{HCl}$ encer, dikeringkan dan kemudian dipanaskan pada suhu $600^{\circ} \mathrm{C}$ selama 5 jam untuk mengurainya menjadi serbuk kuning $\mathrm{PbO}$.

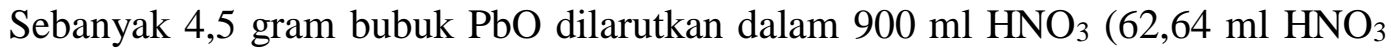
diencerkan dalam akuades) dan distiring. Selama proses stiring, larutan KI (1,66 gram KI dilarutkan dalam $10 \mathrm{ml}$ aquades) diteteskan sedikit demi sedikit dan biarkan proses stiring berlangsung selama 2 jam sampai terbentuk larutan berwarna kuning tua dan dibiarkan mengendap menghasilkan endapan $\mathrm{PbI}_{2}$. Endapan $\mathrm{PbI}_{2}$ dikumpulkan dan dicuci dengan air dingin dan dikeringkan dalam oven vakum selama satu malam. Bubuk $\mathrm{PbI}_{2}$ kemudian dipanaskan pada suhu $100^{\circ} \mathrm{C}$ kurang lebih 1 jam untuk menghilangkan kandungan airnya.

Film $\mathrm{PbI}_{2}$ dibuat dengan melarutkan 461 gram bubuk $\mathrm{PbI}_{2}$ dalam $1 \mathrm{ml} \mathrm{DMF}$ dan kemudian distirring agar menghasilkan larutan yang transparan dan homogen. Film $\mathrm{PbI}_{2}$ dibuat dengan spin-coating menggunakan kecepatan putaran $3000 \mathrm{rpm}$ selama 60 sekon. Film kemudian dianniling pada suhu $150^{\circ} \mathrm{C}$ selama 30 menit. Film perovskite dibuat dengan mencampurkan $461 \mathrm{mg} \mathrm{PbI}_{2}$ dan $159 \mathrm{mg}$ MAI dalam 1 $\mathrm{ml}$ DMF. Larutan distiring selama untuk memperoleh larutan yang homogen. Film perovskite dibuat dengan metode spin-coating satu-tahap menggunakan kecepatan 1500 rpm selama 60 sekon diatas FTO yang telah dilapisi film tipis $\mathrm{TiO}_{2}$ blocking layer dan mesopori. Lapisan $\mathrm{TiO}_{2}$ diperlukan agar film perovskite yang dispincoating lebih stabil terhadap udara dan kelembaban. Pelarut klorobenzen diteteskan setelah 15 sekon proses spin-coating dimulai. Film perovskite kemudian dianiling pada suhu $150^{\circ} \mathrm{C}$ selama 30 menit. Spektroskopi UV-Vis dilakukan untuk mengukur sifat optik dan XRD untuk mengkaji struktur kristal film $\mathrm{PbI}_{2}$ dan film perovskite. 


\section{Hasil dan Pembahasan}

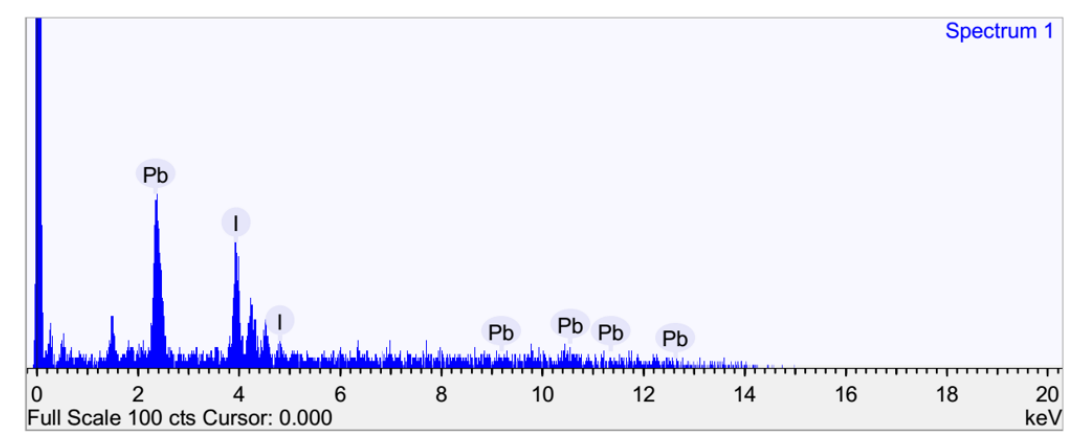

\section{Quantification Settings}

Quantification method: All elements (normalised) Coating element : None

$\begin{array}{llll}\text { Summary results } & & \\ \text { Element } & \text { Weight \% } & \text { Weight \% o } & \text { Atomic \% } \\ \text { lodine } & 55.704 & 3.496 & 67.246 \\ \text { Lead } & 44.296 & 3.496 & 32.754\end{array}$

(a)

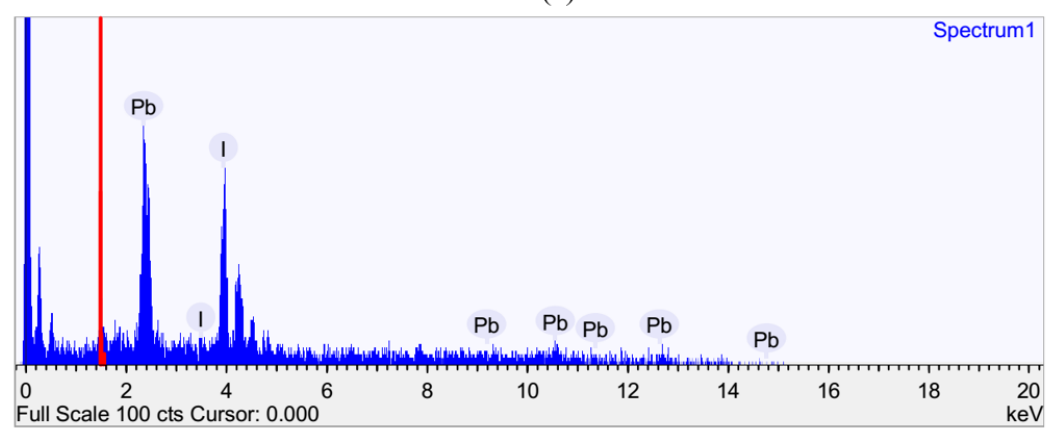

\section{Quantification Settings}

Quantification method:

All elements (normalised)

Coating element :

None

$\begin{array}{llll}\text { Summary results } & & \\ \text { Element } & \text { Weight \% } & \text { Weight \% o } & \text { Atomic \% } \\ \text { lodine } & 59.143 & 3.011 & 70.268 \\ \text { Lead } & 40.857 & 3.011 & 29.732\end{array}$

(b)

Gambar 1. Spektra EDS $\mathrm{PbI}_{2}$ (a). Hasil sintesis dan (b). Produk Sigma Aldrich

Gambar 1 menunjukkan spektra EDS dari $\mathrm{PbI}_{2}$ hasil sintesis dan produk komersial Sigma Aldrich. Tampak bahwa bubuk $\mathrm{PbI}_{2}$ hasil sintesis hanya mengandung unsur timbal $(\mathrm{Pb})$ sebanyak 32,7 \% atomik dan iodin (I) sebanyak 67,25\%. Komposisi ini memperlihatkan bahwa $\mathrm{PbI}_{2}$ hasil sintesis memiliki kemurnian $95 \%$ yang lebih tinggi dibandingkan dengan penelitian sebelumnya [10]. Sebagai perbandingan juga dilakukan pengukuran EDS $\mathrm{PbI}_{2}$ komersial yang memiliki kemurnian di atas 95\%. Hasil komparasi prosentasi atomik menunjukkan bahwa $\mathrm{PbI}_{2}$ hasil sintesis memiliki komposisi yang lebih baik dibandingkan dengan produk komersial Sigma Aldrich. Hasil EDS ini menunjukkan bahwa material $\mathrm{PbI}_{2}$ dari baterai bekas mobil dapat digunakan sebagai material untuk membuat material perovskite. 


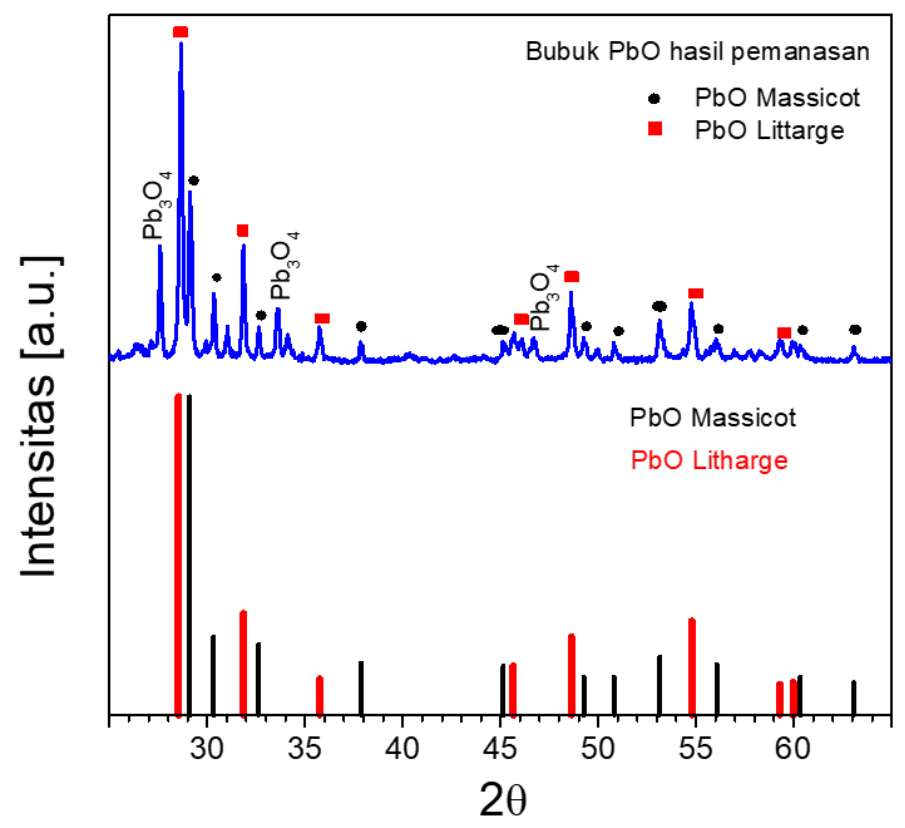

Gambar 2. Pola XRD dari bubuk $\mathrm{PbO}$ hasil sintesis dan JCPDS kristal $\mathrm{PbO}$

Tingkat kemurnian $\mathrm{PbI}_{2}$ dipengaruhi oleh proses pemanasan bubuk $\mathrm{PbO}_{2}$ untuk dikonversi menjadi $\mathrm{PbO}$ pada suhu $600 \mathrm{C}$ selama 5 jam. Dua jenis kristal $\mathrm{PbO}$ dapat dibentuk, yaitu litharge dan massicot [11]. Hasil pengukuran XRD dari bubuk $\mathrm{PbO}$ dan JCPDS dari kedua struktur kristal PbO diperlihatkan pada Gambar 2. Ada beberapa puncak yang bukan menunjukkan kedua struktur kristal baik litharge maupun massicot, yang merupakan kontribusi dari timbal oksida yang lain, khususnya $\mathrm{Pb}_{3} \mathrm{O}_{4}$ yang dapat terbentuk selama proses pemanasan, sesuai dengan reaksi:

$$
\mathrm{PbO}_{2} \rightarrow \mathrm{Pb}_{12} \mathrm{O}_{19} \rightarrow \mathrm{Pb}_{12} \mathrm{O}_{17} \rightarrow \mathrm{Pb}_{3} \mathrm{O}_{4} \rightarrow \mathrm{PbO}
$$

Stoikiometri dari produk akhir dapat dikontrol dengan mengubah dan mengontrol suhu. Misalnya, dalam reaksi di atas, langkah pertama terjadi pada suhu $290^{\circ} \mathrm{C}$, kedua pada suhu $350{ }^{\circ} \mathrm{C}$, ketiga pada suhu $375{ }^{\circ} \mathrm{C}$ dan keempat pada suhu $600{ }^{\circ} \mathrm{C}$. Hal ini berarti proses pembentukan produk tersbut sangat dipengaruhi oleh tahapan proses pemanasan bubuk $\mathrm{PbO}_{2}$.

Pola difraksi sinar-x (XRD) dari bubuk $\mathrm{PbI}_{2}$ hasil sintesis dan produk Sigma Aldrich serta data JCPDS diperlihatkan pada Gambar 3. Pola XRD memiliki puncak-puncak difraksi pada sudut $12,7^{\circ}$ (bidang kristal 001); 26, $0^{\circ}$ (bidang kristal 002); $34,4^{\circ}$ (bidang kristal (003) dan $22,4^{\circ}$ (bidang kristal (004). Ini juga berarti $\mathrm{PbI}_{2}$ hasil sintesis terorientasi dalam satu arah sumbu-c saja. Pola XRD memiliki pola yang sama dengan produk Sigma Aldrich. Hasil perbandingan dengan data JCPDS, menunjukkan bahwa kedua bubuk $\mathrm{PbI}_{2}$ memiliki struktur kristal rombohedral dengan kisi konstanta $\mathrm{a}=\mathrm{b}=4,59 \AA$ dan $\mathrm{c}=6,87 \AA$ dengan space group $\mathrm{P} 3 \mathrm{ml}$ [12]. 


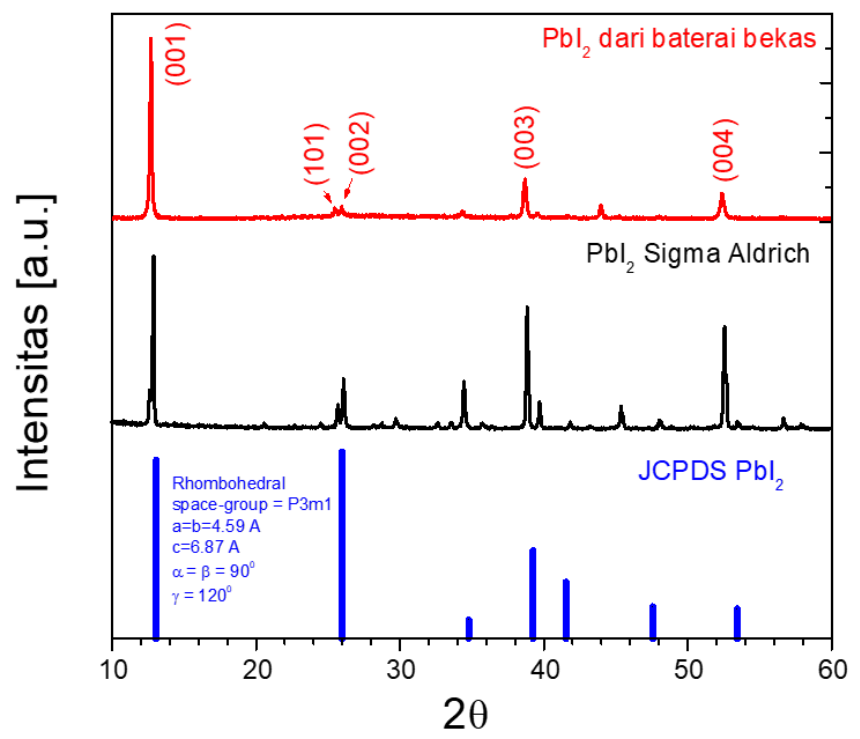

Gambar 3. Pola XRD dari bubuk $\mathrm{PbI}_{2}$ hasil sintesis dan produk Sigma Aldrich serta data JCPDS

Gambar 4 memperlihatkan spektra absorbansi UV-Vis lapisan perovskite dan $\mathrm{PbI}_{2}$ hasil sintesis dan produk Sigma Aldrich. Spektra $\mathrm{PbI}_{2}$ hasil sintesis dan produk komerisl memperlihatkan pola yang sama, yaitu mulai absorpsi cahaya pada panjang gelombang $520 \mathrm{~nm}$. Hal ini berarti kedua produk tersebut memiliki sifat optik yang sama. Penambahan material MAI akan memperbesar daerah serapan cahaya pada panjang gelombang panjang dalam material perovskite. Kedua pola absorbansi perovskite hasil sintesis dan produk komersial juga memiliki pola yang sama.

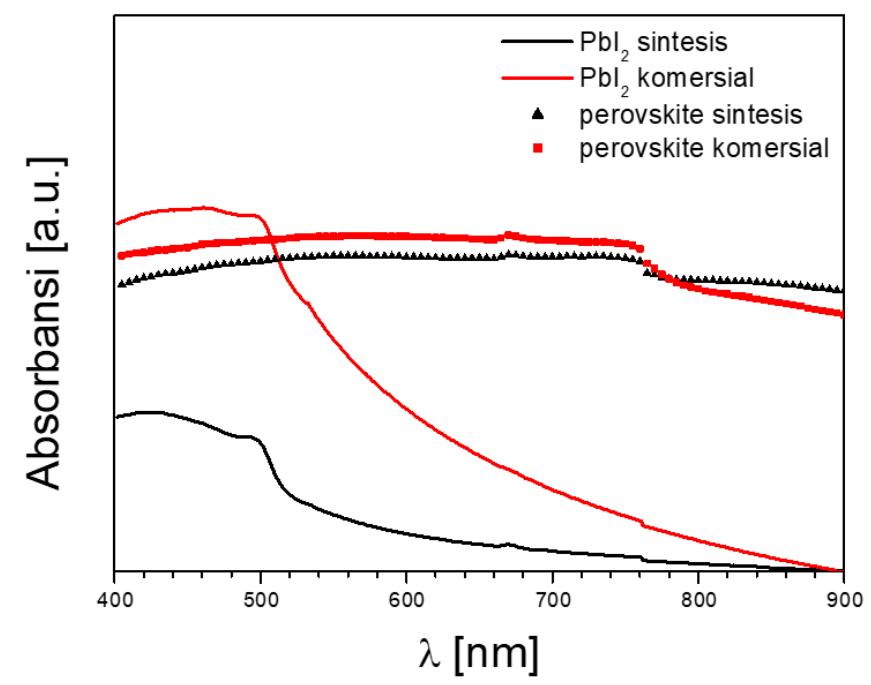

Gambar 4. Spektra absorbansi UV-Vis film $\mathrm{PbI}_{2}$ dan perovskite hasil sintesis dan produk komersial (Sigma Aldrich)

Pola XRD dari film perovskite yang dibuat dari $\mathrm{PbI}_{2}$ hasil sintesis diperlihatkan pada Gambar 5. Film perovskite dibuat di atas lapisan $\mathrm{TiO}_{2}$ yang memiliki struktur kristal anatase (JCPDS 21-1272), seperti tampak pada Gambar 5. Puncak-puncak 
difraksi perovskite diperlihatkan pada sudut $14,14^{\circ} ; 20,04^{\circ} ; 24,50^{\circ} ; 28,48^{\circ}$; $31,86^{\circ} ; \quad 40,6^{\circ}$ dan $43,18^{\circ}$ yang bersesuaian dengan puncak-puncak difraksi berturut-turut bidang kristal (110), (220), (202), (220), (310), (224) dan (314). Pola XRD juga memperlihatkan puncak-puncak dominan pada sumbu $\mathrm{x}-\mathrm{y}$, yang berarti kristal perovskite terorientasi dalam arah bidang $\mathrm{x}-\mathrm{y}$. Terdapat dua puncak difraksi dengan intensitas yang sangat kecil pada sudut $12,66^{\circ}$ dan $23,44^{\circ}$, berasal dari $\mathrm{PbI}_{2}$ yang tidak terkonversi menjadi perovskite atau mengalami degradasi/oksidasi material perovskite menjadi $\mathrm{PbI}_{2}$ yang terjadi dalam rentang waktu setelah spincoating hingga pengukuran XRD. Namun karena intensitas difraksinya sangat kecil, maka dapat disimpulkan bahwa seluruh film adalah perovskite. Pola difraksi perovskite dari $\mathrm{PbI}_{2}$ hasil sintesis memiliki pola yang sama dengan pola difraksi produk komersial (Sigma Aldrich), bahkan lebih banyak $\mathrm{PbI}_{2}$ yang terkonversi menjadi perovskite. Pembuatan lapisan perovskite baik hasil sintesis maupun produk komersial yang dibuat di atas lapisan $\mathrm{TiO}_{2}$ juga lebih stabil terhadap kelembaban udara dibandingkan film yang dibuat di atas substrat saja [13].

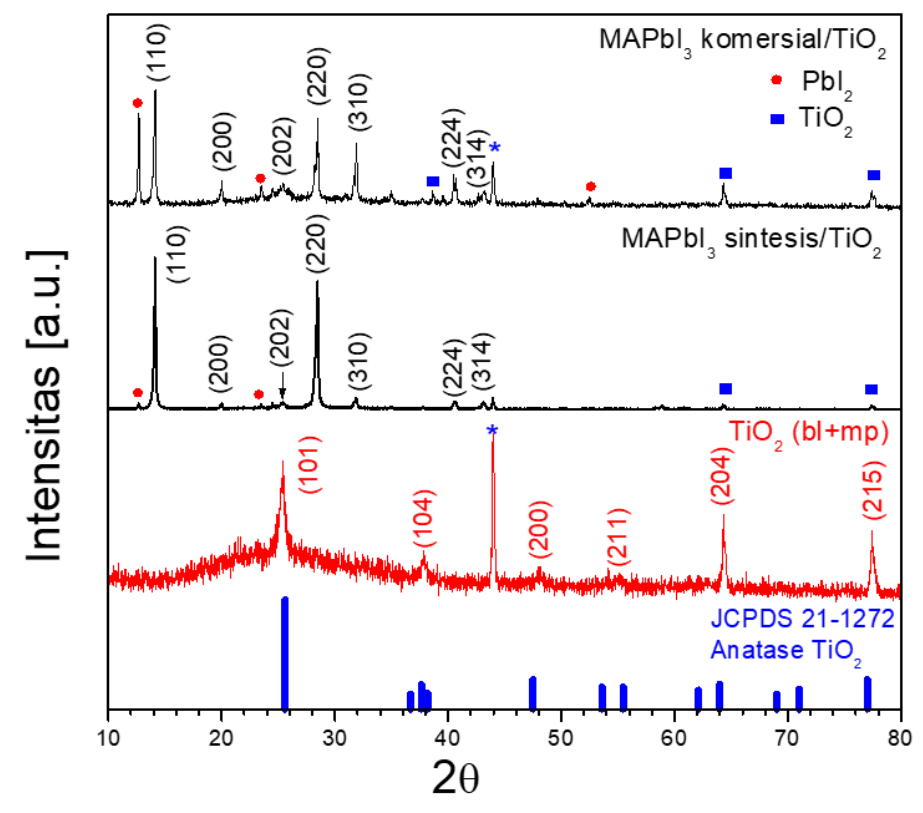

Gambar 5. Pola XRD film perovskite yang dibuat dari $\mathrm{PbI}_{2}$ hasil sintesis di atas lapisan $\mathrm{TiO}_{2}$

\section{Kesimpulan}

Telah berhasil disintesis material bubuk $\mathrm{PbI}_{2}$ dari anoda baterai bekas mobil melalui reaksi kimia sederhana. Hasil EDS memperlihatkan bahwa hasil sintesis memiliki kemurnian 95 prosen dengan komposisi atomik yang lebih baik dibandingkan dengan produk komersial Sigma Aldrich. Hasil spektroskopi UV-Vis dan XRD memperlihatkan bahwa film $\mathrm{PbI}_{2}$ dan perovskite memiliki pola yang sama dengan film dari produk Sigma Aldrich. Pola XRD film provskite dari $\mathrm{PbI}_{2}$ hasil sintesis menunjukkan kristal perovskite dengan orientasi dominan pada arah sumbu x-y. Material $\mathrm{PbI}_{2}$ hasil sintesis dari baterai bekas mobil dapat digunakan sebagai bahan untuk membuat perovskite dengan kualitas yang sebanding produk komersial. Dengan demikian, timbal dalam baterai bekas dapat digunakan sebagai material aktif sel-surya perovskite dengan biaya murah dan juga dapat meningkatkan nilai tambah kekonomian dari baterai bekas mobil. 


\section{Ucapan terima kasih}

Penelitian ini didanai oleh Kementerian Riset Teknologi dan Pendidikan Tinggi melalui Penelitian Unggulan Perguruan Tinggi (PUPT) tahun 2016 berdasarkan surat pelaksanaan hibah penelitian no. 125/SP2H/LT/DRPM/III/2016 tanggal 10 Maret 2016.

\section{Daftar Pustaka}

1. D. Erlangga, Cadangan minyak di Indonesia hanya cukup untuk 23 tahun Lagi, http://bisniskeuangan.kompas.com/read/2014/09/15/095100426/Cadangan.Mi nyak.di.Indonesia.Hanya.Cukup.untuk.23.Tahun.Lagi. [Accessed 28 September 2014].

2. L. E. Chaar, L. A. Iamont and N. E. Zein, Review of photovoltaic technologies, Renewable and Sustainable Energy Reviews, vol. 15, (2011), 2165-2175.

3. V. V. Tyagi, N. A. A. Rahim, N. A. Rahim, J. A. L. Selvaraj, Progress in solar PV technology: Research and achievement, Renewable and Sustainable Energy Reviews, vol. 20, (2013), 443-461.

4. A. Fakharuddin, R. Jose, T. M. Brown, F. F. Santiago and J. Bisquert, A perspective on the production of dye-sensitized solar modules, Energy \& Environmental Science, vol. 7, (2014), 3952-3981.

5. N. Espinosa, R. G. Valverde, A. Urbina, F. Lenzmann, M. Manceau, D. Angmo and F. C. Krebs, Life cycle assessment of ITO-free flexible polymer solar cells prepared by roll-to-roll coating and printing, Solar Energy Materials \& Solar Cells, vol. 97, (2012), 3-13.

6. J. Burschka, N. Pellet, S. J. Moon, R. H. Baker, P. Gao, M. K. Nazeeruddin and M. Grätzel, Sequential deposition as a route to high-performance perovskitesensitized solar cells, Nature, vol. 499,( 2013), 316-319.

7. N. J. Jeon, J. H. Noh, Y. C. Kim, W. S. Yang, S. Ryu and S. I. Seok, Solvent engineering for high-performance inorganic-organic hybrid perovskite solar cells, Nature Materials, vol. 13, (2014), 1-7.

8. H. Zhou, Q. Chen, G. Li, S. Luo, T.-b. Song, H. S. Duan, Z. Hong, J. You, Y. Liu, Y. Yang, Interface engineering of highly efficient perovskite solar cells, Science, vol. 345, (2014), 542-546.

9. E. H. Anaraki, A. Kermanpur, L. Steier, K. Domanski, T. Matsui, W. Tress, M. Saliba, A. Abate, M. Graetzel, A. Hagfeldt, J.-P. Correa-Baena, Highly efficient and stable planar perovskite solar cells by solution-processed tin oxide, Energy \& Environmental Science, vol. 9, (2016), 3128-3134.

10. I. Dhiaputra, B. Permana, Y. Maulana, Y. D. Inayatie, Y. R. Purba and A. Bahtiar, Composition and crystal structure of perovskite films attained from electrodes of used car battery, AIP Conference Proceedings 1712, (2016), 050013 (5-pages).

11. H. Harada, Y. Sasa, M. Uda, Crystal data for $\square-\mathrm{PbO}_{2}$, Journal of Applied Crystallography Vol. 14, (1981), 141-142.

12. C.A. Sutherland, E.F. Milner, R.C. Kerby, H. Teindl, A. Melin, and H.M. Bolt, Ullmann's Encyclopedia of Industrial Chemistry, 2005. John Wiley and Sons Inc. New York, USA.

13. A. Bahtiar, S. Rahmanita and Y. D. Inayatie, Pin-hole free perovskite film for solar cells application prepared by controlled two-step spin-coating method, IOP Conf. Series: Materials Science and Engineering Vol. 196, (2017), 012037 (7-pages). 